\title{
A modified test for Brucella agglutinins
}

\author{
J. N. SINGH \\ From the Microbiological Diagnostic Unit, School of Microbiology, University of Melbourne
}

SYNOPSIS $\quad 0 \cdot 1 \%$ Protamine sulphate in normal $(0.85 \% \mathrm{w} / \mathrm{v})$ saline has been used as a diluent in Brucella serology instead of saline as such. The use of protamine sulphate in this concentration has obviated the need for performing the modified Coombs test to detect non-agglutinating Brucella antibodies.

This method has been used in the Microbiological Diagnostic Unit of the University of Melbourne in the routine titration of 721 sera and has proved to give reliable and reproducible results.

The diagnosis of brucellosis often presents a difficult clinical and bacteriological problem. Harris (1946) has noted how readily brucellosis and psychoneurosis can be confused. Wilson (1957) estimated that the causative organism can only be isolated from $10 \%$ of those cases in which infection causes symptoms so it is not surprising that DalrympleChampneys (1960) suggested that only one case of brucellosis in 10 is diagnosed and notified.

The Joint FAO/WHO Expert Committee on Brucellosis (De Mello, 1963) after reviewing a number of diagnostic techniques, namely, blood culture, animal inoculation, skin tests, surface fixation, complement-fixation, and tube agglutination tests, considered that the last of these was the only reliable procedure for the diagnosis of individual cases of brucellosis. The direct tube agglutination test was described in 1930 (Fitch, Donham, Bishop, and Boyd, 1930) and has remained virtually unaltered since then. It is satisfactory in the large majority of cases but an appreciable proportion of patients, particularly those in the chronic phase of the illness, may possess non-agglutinating antibodies (Jones and Wilson, 1951).

Wilson and Merrifield (1951) made a significant contribution to the problem created by these antibodies by introducing the Coombs modification in which these non-agglutinating antibodies are demonstrated by the use of antihuman globulin. This greatly improved the test for antibodies to brucella but doubled the time taken for its performance.

Protamine sulphate in isotonic saline was used by Vaughan and Walter (1954) and by Roth and Frumin (1954) to detect antibodies in haemolytic anaemia which could otherwise only be demonstrated by the Coombs modification. It, therefore, seemed approReceived for publication 14 January 1969. priate to try protamine sulphate in the test for Brucella antibodies and this paper records the success achieved.

\section{MATERIALS AND METHODS}

Brucella abortus strains, both carbon dioxide sensitive and independent, were kept in the lyophilised state. The dried organisms were resuscitated by suspending in Brucella (Albimi) broth and incubating in air or in 10\% $\mathrm{CO}_{2}$-air for 16 to 18 hours at $37^{\circ} \mathrm{C}$. The broth cultures were then plated out on Albimi agar plates. Single colonies were confirmed as Brucella abortus serologically.

BRUCELLA AGGLUTINATING SUSPENSION Using the above strains, an agglutinating suspension was prepared and standardized as recommended by the Standards Laboratory, Central Public Health Laboratory, Colindale.

Protamine sulphate This was obtained from Koch-Light Laboratories, Bucks, England. A $1 \%$ stock solution was made by dissolving $1 \mathrm{~g}$ of protamine sulphate in $100 \mathrm{ml}$ of normal $(0.85 \% \mathrm{w} / \mathrm{v})$ saline. A $0.1 \%$ solution was prepared by mixing $10 \mathrm{ml}$ of stock solution in $90 \mathrm{ml}$ of normal saline.

Coombs reagent (batch $\mathrm{K} 7459$ ) This was obtained from the Wellcome Research Laboratories, Beckenham, England, and was stored at $4^{\circ} \mathrm{C}$. It was generally used at a dilution of $1 / 30$ (prepared in normal saline). The diluted serum was kept at $-20^{\circ} \mathrm{C}$. As repeated freezing and thawing reduces the titre of this reagent, only small volumes of diluted serum were prepared at any one time.

Preparation of glassware Pyroneg (Diversey, A/asia), $1 / 3 \mathrm{oz}$, was dissolved in 1 gallon of water at $48^{\circ}$ to $52^{\circ} \mathrm{C}$. Dreyer tubes, bottles, etc, previously rinsed in tap water, were soaked in this detergent solution overnight. Next day the tubes were rinsed in two to three changes of tap water and then dried.

Sources of sera Most of the sera used in this project came from rural districts, from dairy farmers and allied workers who were suspected of suffering from brucellosis. 
TABLE I

EFFICIENCY OF 0.1\% PROTAMINE SULPHATE AS A DILUENT TO DETECT NON-AGGLUTINATING BRUCELLA ANTIBODIES IN HEATED AND UNHEATED SERA

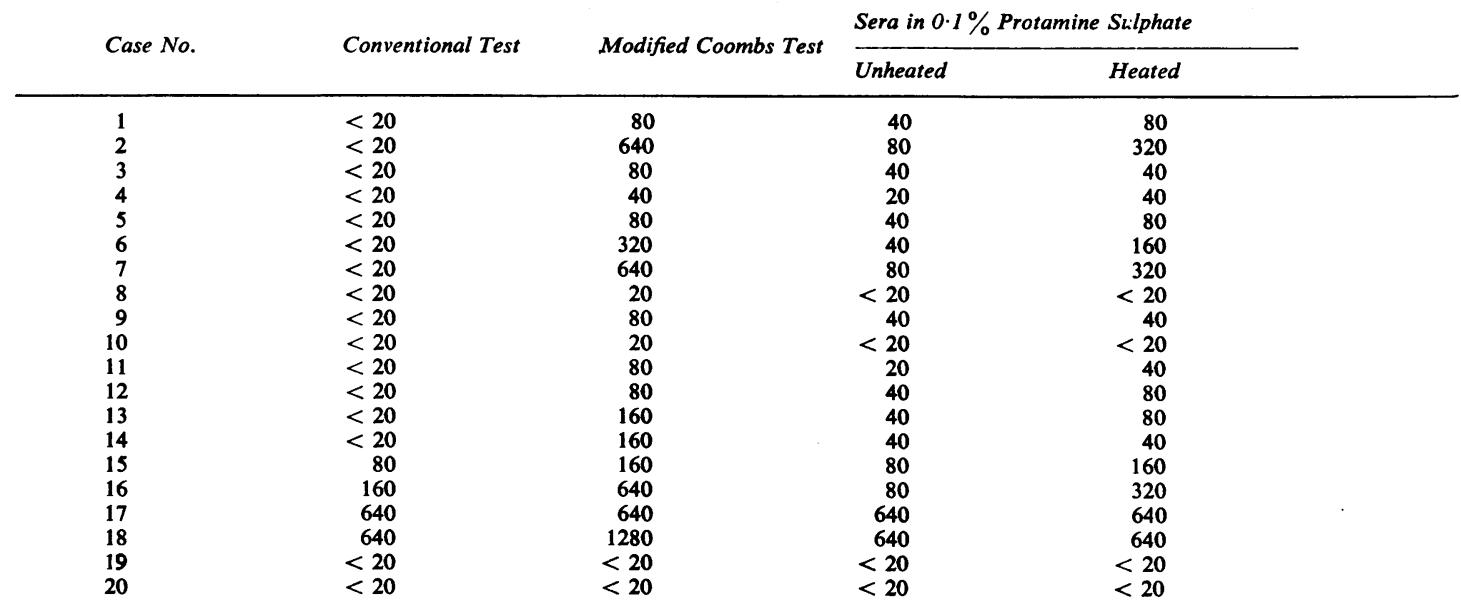

A much smaller number of sera came from suspected cases in the Melbourne metropolitan area.

PERFORMANCE OF TESTS FOR BRUCELLA ANTIBODY The conventional agglutination test was performed by adding equal volumes of the standardized Brucella suspension to serial dilutions, from $1 / 10$ to $1 / 2,560$, of sera in normal saline, in Dreyer tubes.

The tubes were examined for agglutination after being incubated at $37^{\circ} \mathrm{C}$ for 16 hours.

With protamine sulphate In this the conventional technique was employed but the sera were diluted in $0.1 \%$ protamine sulphate in normal saline.

Modified Coombs test This procedure was carried out as recommended by Wilson and Merrifield (1951).

\section{RESULTS}

Twenty sera which had showed a wide range of Brucella antibody titres by the conventional agglutination and antiglobulin tests were re-tested in parallel with the agglutination test employing the protamine sulphate diluent.

Preliminary experiments (Singh, 1968) had indicated that when protamine sulphate was used it was necessary to heat the sera at $56^{\circ} \mathrm{C}$ for 30 minutes, before testing, to get optimal results. Therefore, in the parallel tests the protamine sulphate diluent was used with both heated and unheated sera.

The results of the parallel tests are shown in Table I.

\section{DISCUSSION}

The failure of the conventional agglutination test in chronic brucellosis and the success of the complement-fixation test and of the Coombs modification are consistent with the appearance of non-agglutinating $7 \mathrm{~S}$ antibody.

Amerault, Manthei, Good, and Lambert (1961) heated sera to remove non-specific reactions when testing for bovine brucellosis but the use of protamine sulphate in tests for brucellosis has not been described before. The exact mechanism of its action is not fully understood. Various explanations have included suggestions that reaction sites on the antibody molecule are 'opened up' and that electrostatic forces repelling molecules of antigen and antibody are reduced as by the addition of bovine serum albumin (Pollack, 1965).

The modified agglutination test using heated sera and a protamine-sulphate-containing diluent has had its value confirmed by parallel trials with conventional methods by other members of the staff of this School (Rubbo, 1969). Since May 1968 it has been used as a routine technique in the diagnostic unit for the examination of 721 sera and has proved to give reliable and reproducible results effectively correlated with clinical findings, but more extensive studies over prolonged periods are planned before recommending it for general acceptance.

I wish to thank Professor Sydney D. Rubbo, Chairman of the School of Microbiology, University of Melbourne, for allowing this project to be conducted in the Department and for permission to publish this paper. Advice and criticism from the Assistant Director, Dr J. R. L. Forsyth, is gratefully acknowledged. 
REFERENCES

Amerault, T. E., Manthei, C. A., Good, E. R., Jr., and Lambert, G. (1961). Amer. J. vet. Res., 22, 564.

Dalrymple-Champneys, W. (1960). Brucella Infection and Undulant Fever in Man. Oxford University Press, London.

De Mello, M. T. (1963). WHO/BRUC/279.

Fitch, C. P., Donham, C. R., Bishop, L. M., and Boyd, W. L. (1930). Tech. Bull. Minn. Agric. exp. Stn., 73, 1.
Harris, H. J. (1946). J. Amer. Med. Ass., 131, 1485.

Jones, L. O., and Wilson, M. M. (1951). Nature (Lond.), 167, 558.

Pike, R. M. (1967). Bact. Rev., 31, 157.

Pollack, W. (1965). Ann. N.Y. Acad. Sci., 126, 892.

Roth, K. L., and Frumin, A. M. (1954). Science, 120, 945.

Rubbo, S. D. (1969). To be published.

Singh, J. N. (1968). Thesis.

Vaughan, J. H., and Walter, M. V. (1954). Clin. Res. Proc., 2, 114.

Wilson, M. M. (1957). Med. J. Aust., 2, 413.

-, and Merrifield, E. V. O. (1951). Lancet, 2, 913. 